\title{
Análise do Processo da Comunicação Contábil: Uma Contribuição para a Solução de Problemas Semânticos, Utilizando Conceitos da Teoria da Comunicação*
}

\author{
José Maria Dias Filho \\ Mestrando em Controladoria e Contabilidade da FEA/USP - Professor da Universidade Estadual de Feira \\ de Santana - BA
}

Masayuki Nakagawa

Pesquisador e Coordenador de Projetos da Fipecafi-FEA/USP

RESUMO

Tendo em vista que a compreensibilidade das informações contábeis é um dos atributos necessários para que a Contabilidade possa servir ao processo decisório, o presente trabalho procura discutir até que ponto os usuários de tais informações conseguem compreender a terminologia empregada na evidenciação contábil.

A literatura revela que a preocupação com o aspecto da compreensibilidade na área contábil não é nova, mas nota-se que ela vem aumentando na medida em que o leque de usuários das informações contábeis se amplia, quer seja impulsionado pelo fenômeno da globalização de mercados, quer pelo progresso das tecnologias da informação. Além disso, observa-se que os usuários mais tradicionais, tais como fornecedores, clientes e investidores, tornam-se mais exigentes em relação à quantidade e à qualidade das informações que lhes são oferecidas.

Tomando-se por base a literatura corrente e alguns resultados de pesquisas, levanta-se a hipótese de que muitos termos empregados nas demonstrações contábeis não são compreendidos por seus destinatários ou são interpretados de maneira diferente da que se pretendia. Alega-se que uma das prováveis causas desse desencontro entre significados pretendidos e alcançados não reside apenas no uso de termos eminentemente técnicos, mas também no hábito de os contadores atribuírem significados técnicos a palavras que são utilizadas com sentido diferente na linguagem comum. A título de exemplo, cite-se que o usuário tanto
ABSTRACT

Considering the understandability of accounting information as one of the necessary attributes for Accounting to be able to assist in the decision-making process, this paper discusses to which degree the users of such information manage to understand the terminology used in accounting disclosure.

Literature reveals that, although the preoccupation with the understandability aspect in accounting is not new, it is increasing to the extent that the variety of users of accounting information is amplified, whether this is urged by the phenomenon of market globalization, or by the progress of information technology. Besides, it is observed that the most traditional users, such as suppliers, clients and investors, are becoming more demanding in relation to the quantity and quality of the information they are offered.

On the basis of current literature and some research results, the hypothesis is brought up that many terms used in financial statements are not understood by the persons they are destined for, or are interpreted in a different way than what was pretended. It is alleged that one of the probable causes of this lack of correspondence between intended and attained meanings lies not only in the use of eminently technical terms, but also in the habit of accountants to attribute technical meanings to words used with a different meaning in common language. As an example, we quote that the user can not only ignore the accounting meaning of a term like goodwill, but can also attribute an unwanted meaning to the term depreciation.

* Artigo originalmente apresentado no XVI Congresso Brasileiro de Contabilidade, realizado em Goiânia de 15 a 20 de outubro de 2000 
pode ignorar o significado contábil de um termo como goodwill, como também atribuir um significado diferente do desejado ao termo depreciação.

Se isso pode ocorrer com usuários mais familiarizados com a terminologia contábil, a exemplo de investidores, credores e outros semelhantes, o que pode ser dito em relação aos menos tradicionais, tais como entidades de proteção ambiental, organizações não governamentais voltadas para a defesa dos direitos humanos, ou até mesmo o cidadão comum que, por si próprio, recorra a demonstrações contábeis para conhecer a relação das empresas com o ambiente onde opera?

Diante disso, e considerando que a Contabilidade se caracteriza como um processo de comunicação, propõe-se que se utilizem os conceitos da Teoria da Comunicação para desenvolver e aprimorar metodologias que permitam ajustar a terminologia utilizada na evidenciação contábil às características e necessidades de seus usuários. Se a referida Teoria tem sido utilizada com muito êxito em diversos ramos do conhecimento humano, tais como a economia, a psicologia e a biofísica, é provável que a Contabilidade também possa extrair proveito de seu arcabouço conceitual para alcançar maior eficácia no processo de comunicação das informações contábeis.

Palavras-Chave: evidenciação, teoria da comunicação, qualidades da informação, processo decisório.
If this can occur with those users that are more familiar with accounting terminology, such as, for example, investors, creditors and other similar users, what can be said then about the less traditional users, such as environmental protection entities, non-governmental organizations in defense of human rights, or even the common citizen who, by himself, turns to financial statements to know about the relation between companies and the environment they work in.

In view of what was mentioned above, and considering that Accounting is characterized as a communication process, the use of concepts from Communication Theory is proposed, in order to develop and improve methodologies that allow for the adjustment of the terminology used in accounting disclosure to the characteristics and necessities of its users. If the Theory referred to has been used very successfully in various areas of human knowledge, such as economy, psychology and biophysics, it is probable that Accounting will also be able to take advantage of its conceptual framework in order to reach a higher level of efficacy in the accounting information communication process.

Key words: disclosure, communication theory, information qualities, decision-making process.
1. INTRODUÇÃO

Apesar do entendimento geral de que a comunicação é função básica da atividade contábil, na medida em que se reconhece que sua missão é identificar, mensurar e comunicar os eventos que afetam o patrimônio das entidades, poucas pesquisas têm sido realizadas, em nosso meio, no sentido de investigar se a linguagem utilizada na evidenciação contábil permite uma compreensão satisfatória dos elementos que podem afetar as decisões econômico-financeiras dos usuários da Contabilidade.

Considerando que o entendimento das informações contábeis constitui requisito essencial para que as mesmas sejam utilizadas adequadamente no processo decisório, o presente trabalho procura estimular reflexões no sentido de se avaliar até que ponto a Contabilidade tem conseguido estabelecer uma comunicação eficaz entre a empresa e os diversos agentes que com ela interagem, tais como acionistas, clientes, fornecedores, empregados, entidades governamentais, entre outros que se apoiam na evidenciação contábil para melhorar a qualidade de suas decisões.

As discussões deverão se concentrar sobre a dimensão semântica das informações contábeis e terão como suporte os princípios da Teoria da Comunicação, bem como algumas pesquisas realizadas em diversos países com o objetivo de aferir o grau de compreensibilidade das referidas informações.

Outro objetivo deste trabalho é demonstrar que os conceitos da Teoria da Comunicação podem contribuir no desenvolvimento de metodologias voltadas para identificar e corrigir problemas semânticos que afetam as informações contábeis. A hipótese que orienta as reflexões é a de que o usuário médio das 
informações contábeis não consegue assimilar adequadamente o seu conteúdo por desconhecer muitos termos empregados na evidenciação ou por lhes atribuir significados diferentes daqueles que o contador normalmente pretende transmitir. Nestas circunstâncias, entende-se que tais informações não sejam bem aproveitadas como instrumento de apoio ao processo decisório.

\section{CARACTERIZAÇÃO GERAL DO PROBLEMA}

\subsection{Perspectiva Histórica}

Há muito tempo, a dimensão semântica das informações contábeis vem despertado a atenção de diversos autores e entidades que se preocupam com a qualidade da evidenciação. Hendriksen (1999), por exemplo, explica que os números e as classificações contábeis sofrem variações quanto à interpretação que o usuário das demonstrações poderá atribuir aos mesmos. Exemplificando, esse autor afirma que o item caixa normalmente é compreendido como os contadores o desejam, porém o mesmo não se verifica em relação à expressão despesas diferidas. Para esse termo, segundo Hendriksen, não há qualquer interpretação específica além dos processos estruturais que lhe deram origem.

$\mathrm{Na}$ obra referenciada, Hendriksen destaca que a preocupação das teorias que se concentram no aspecto semântico da linguagem contábil é encontrar formas de melhorar a interpretação das informações contábeis a partir da observação e da experiência humanas. Referindo-se à importância desse assunto, o autor lembra que o Financial Accounting Standards Board - FASB, em particular, está sempre procurando livrar o balanço de itens que careçam de conteúdo semântico.

Além do FASB, tanto a Associação Americana de Contabilidade - AAA como o Instituto Americano de Contadores Públicos Certificados- AICPA têm dedicado alguma atenção a esse problema, especialmente no que se refere a informações contábeis voltadas para usuários externos. Em 1920, o AICPA estabeleceu um Comitê de Terminologia com o propósito inicial de compilar um conjunto de palavras e expressões utilizadas com maior frequência pela Contabilidade, objetivando fixar significados mais precisos para cada uma delas. Desse esforço inicial, resultou uma espécie de manual intitulado "Accounting Terminology", que foi publicado em 1931, em caráter experimental. Posteriormente, o mesmo comitê preparou um relatório mais amplo contendo uma grande quantidade de definições de termos utilizados pela Contabilidade, mas o mesmo não chegou a ser publicado em razão de muitas polêmicas que acabou provocando. No período de 1939 a 1953, oito documentos semelhantes foram preparados por esse Comitê e publicados sob o título de "Accounting Research Bulletins", os quais foram consolidados e publicados como "Boletim de Terminologia n‥ 1".

O plano original do grupo de estudos envolvido com questões terminológicas era reunir um conjunto de pessoas representativas de diversos segmentos sociais que faziam uso de termos semelhantes aos utilizados pela Contabilidade para construir definições que fossem compreendidas por ampla maioria. Imaginava-se que se um grupo constituído por contadores, advogados, economistas, financistas, gerentes, bancários, líderes sindicais, consultores de empresas e outros congêneres chegassem a um consenso sobre o significado de termos contábeis, todos os demais grupos de usuários poderiam adotá-los sem dificuldades. Entretanto, maiores esforços foram direcionados para questões ligadas a mensuração, em virtude de rápidas variações de preços que afetaram o ambiente econômico, deixando-se de organizar a desejada terminologia "comum".

Uma revisão das recomendações contidas nos citados Boletins indica que, além de desenvolver definições para aplicação geral no campo contábil, em algumas situações o Comitê dirigiu atenção para problemas de uniformidade e para dificuldades semânticas geradas pelo uso de termos que também eram empregados na linguagem comum. Constatou-se que os maiores problemas de interpretação das informações contábeis estavam relacionados com o uso de palavras que, apesar de muito difundidas na linguagem cotidiana, eram empregadas com sentido muito diferente pela Contabilidade. Em alguns casos, o Comitê recomendou a substituição de palavras dessa natureza ou então procurou esclarecer o significado contábil, conforme se verificou em relação aos seguintes termos: "depreciation", "asset", "liability" e "value". Entre os termos indicados para substituição, destacam-se: "reserve", "surplus" e "bookvalue". Destas considerações, depreende-se que, em algu- 
mas situações, o comitê entendeu que certos termos utilizados pela Contabilidade, embora isentos de uso comum, precisavam sofrer alguns ajustes conceituais para alcançar significados mais precisos entre os usuários das informações contábeis. Já, em outras casos, percebeu-se que a melhor solução seria descontinuar o uso de termos muito encastelados na linguagem comum sempre que incorporassem significados diferentes daqueles que com eles se pretendia transmitir no campo da Contabilidade.

No tocante à Associação Americana de Contabilidade, esforços foram empreendidos por essa entidade, notadamente no período de 1936 a 1964, no sentido de clarificar e de integrar determinados termos contábeis. Algumas contribuições foram oferecidas ao desenvolvimento de conceitos relevantes, tais como entidade, realização, confronto entre receitas e despesas, etc. Contudo, muito pouco foi realizado para resolver problemas de natureza essencialmente semântica, a não ser quando se recomendou que a palavra "reserve" deixasse de ser utilizada em demonstrações contábeis de publicação obrigatória, por considerá-la de entendimento muito confuso para a maioria dos usuários. Mesmo assim, cabe salientar que esse órgão compartilhava do entendimento de que a maneira como as informações contábeis eram comunicadas exigia elevada capacidade de compreensão por parte do usuário.

No Brasil, observa-se que a qualidade da evidenciação contábil tem evoluído nas últimas décadas, sobretudo no campo das companhias abertas, em função de contribuições de algumas entidades como a Comissão de Valores Mobiliários - CVM, - Instituto Brasileiro de Pesquisas Contábeis, Atuariais e Financeiras - IPECAFI/USP, o Conselho Federal de Contabilidade e o Instituto Brasileiro dos Contadores - IBRACON. Nota-se que esforços têm sido empreendidos por essas entidades no sentido de melhorar o poder informativo das demonstrações contábeis, seja através de pesquisas, de pronunciamentos técnicos ou de programas de qualificação profissional. Aliás, o próprio IBRACON, ao estabelecer a Estrutura Conceitual Básica da Contabilidade, em 1986, em parceria com o IPECAFI, procurou alertar para o aspecto da compreensibilidade das informações contábeis, declarando que falhas de comunicação decorrentes de problemas de linguagem estão entre os fatores que podem explicar uma even- tual queda no grau de utilização das informações contábeis.

No que se refere à Lei das Sociedades por Ações (6.404/76), embora tenha representado um passo muito importante rumo à evolução do nível de evidenciação contábil no Brasil, observa-se que essa norma incorreu em algumas falhas terminológicas, incorporando termos pouco esclarecedores, tais como "ativo diferido", "resultado de exercícios futuros" e outros. Espera-se que problemas dessa natureza sejam corrigidos quando de sua reformulação.

\subsection{A Natureza do Problema Semântico}

Num processo de comunicação, o problema semântico diz respeito à distância existente entre o significado que um emissor pretende transmitir através de determinado código e a interpretação que o receptor atribui à mensagem recebida. De acordo com Berlo (1999:41-73), para minimizar esse problema, é necessário utilizar códigos lingüísticos que permitam a melhor aproximação possível entre significados pretendidos e alcançados.

Assim, na área contábil, a dificuldade de ordem semântica se manifesta quando o significado que o contador pretende atribuir a termos e expressões veiculados nas demonstrações contábeis se distancia daquele que realmente lhes é atribuído pelos respectivos destinatários. Segundo Haried (1970), esse desencontro entre significados tanto pode ocorrer em relação a expressões eminentemente técnicas e específicas da área contábil, como também em relação a termos que possuem significados bem definidos na linguagem de uso comum, mas são utilizados com conotação diferente no meio contábil.

Para melhor compreensão do problema ora abordado, torna-se necessária uma visão inicial acerca do processo de comunicação das informações contábeis. Segundo Bierman e Drebin (1979:258), um modelo básico de comunicação, em sentido amplo, é constituído dos seguintes elementos:

$\checkmark$ uma fonte de informação que produz uma mensagem, ou seqüência de mensagens a serem comunicadas ao receptor;

$\square$ um transmissor que opera a mensagem de alguma forma para produzir um sinal passível de ser transmitido através do canal;

$\checkmark$ canal, que é o meio utilizado para se transmitir o sinal; 
$\square$ receptor, que realiza a operação inversa do transmissor, reconstruindo a mensagem a partir do sinal; e

$\square$ destino, que é a pessoa para a qual a mensagem é dirigida.

Num sistema contábil, os referidos elementos podem ser visualizados da seguinte forma: os eventos econômicos são as fontes básicas da informação contábil; o contador atua como transmissor, observando estes eventos e codificando-os para transmitir a informação através dos relatórios contábeis, os quais, por sua vez, formam o canal básico desse tipo de comunicação. Finalmente, a mensagem é recebida, decodificada e interpretada pelo administrador ou tomador de decisão, que figura no processo como destinatário final.

De acordo com Bierman e Drebin (1979:258-9), em termos práticos, o sistema contábil se apresenta um pouco mais complexo do que o descrito, haja vista que muitos subsistemas também participam desse processo. A título de exemplo, os autores lembram que, na realidade, raramente o contador observa os fenômenos econômicos de forma direta, mas por meio de diversos documentos, como notas fiscais, recibos, canhotos de cheques, etc. Porém, essa estrutura básica do modelo de comunicação é válida para efeitos de análise de muitos problemas que afetam a qualidade das informações contábeis, particularmente no tocante ao aspecto da compreensibilidade.

Essa visão sistêmica do processo de comunicação procura facilitar o entendimento de que o problema semântico associado à informação contábil deve ser considerado de forma contextualizada, isto é, partindo do sistema emissor até se chegar ao destinatário. Ao receber informações sobre os eventos econômicos, o contador deve interpretá-las fielmente, selecionar o conteúdo de interesse do usuário e codificá-lo de forma compreensível.

Desse modo, entende-se por que compreensibilidade também passa a ser um conceito chave no processo da comunicação contábil. Esse aspecto será analisado em maior profundidade no decorrer deste trabalho, de forma que essa abordagem preliminar objetiva apenas facilitar a compreensão dos seguintes problemas:

$\square$ em geral, os usuários das informações contábeis compreendem satisfatoriamente a terminologia empregada pela Contabilidade?

$\square$ em caso negativo, quais os termos que mais contribuem para que se estabeleçam problemas de ordem semântica nas informações contábeis?

$\square$ qual a contribuição que a Teoria da Comunicação pode oferecer para melhorar a eficiência do processo de comunicação entre a Contabilidade e os usuários das informações contábeis?

Estas são as questões para as quais o presente trabalho pretende levantar respostas, ou, pelo menos, provocar reflexões e estimular pesquisas.

\section{JUSTIFICATIVAS}

Se a eficácia de qualquer processo de comunicação exige, entre outras coisas, que os produtores da informação e seus destinatários atribuam os mesmos significados aos códigos lingüísticos utilizados, há de se admitir que o aprimoramento do potencial de evidenciação dos demonstrativos contábeis requer pelo menos uma avaliação periódica do grau de compreensibilidade da terminologia empregada pela Contabilidade. Entende-se que esse é o primeiro passo necessário para que eventuais ajustes sejam efetuados objetivando adequar a terminologia contábil à capacidade de compreensão dos usuários das informações contábeis.

A preocupação com a linguagem contábil tende a aumentar na medida em que o leque de agentes interessados em informações contábeis se amplia, passando a incorporar elementos de características bem diversificadas em relação aos tradicionais. Como exemplo, temos: organizações não governamentais voltadas para a proteção ambiental e para a defesa dos direitos humanos, associações comunitárias, agremiações políticas e até mesmo o cidadão que, individualmente, pode se interessar por informações de natureza contábil para fazer julgamentos acerca do desempenho das empresas e de suas relações com a sociedade. Com o progresso da tecnológica da informação e a conseqüente diminuição de barreiras geográficas, deverão surgir novas categorias de usuários, exigindo-se cada vez mais aprimoramentos no processo da comunicação contábil.

Diante disso, parece ser relevante verificar se a terminologia utilizada na produção das informações 
contábeis é compatível com os referenciais cognitivos atuais, haja vista que os processos perceptivos se alteram em função do contexto, fazendo da comunicação um fenômeno essencialmente dinâmico, inserido numa dimensão psicossocial.

A necessidade de pesquisas relacionadas com a função da comunicação contábil tem sido destacada por diversos autores. Alguns já vêm utilizando o aparato conceitual da Teoria da Comunicação para avaliar até que ponto os usuários dos demonstrativos contábeis conseguem compreender o seu conteúdo. Haried (1970:226), por exemplo, constatou a existência de problemas semânticos em demonstrações contábeis dirigidas a usuários externos. Num estudo comparativo destinado a avaliar técnicas de pesquisas aplicadas à Contabilidade, esse autor observou que a maior fonte de problemas semânticos na área contábil está relacionada com a tendência de se atribuirem significados técnicos a termos que têm conotações diferentes e bem consolidadas no meio popular, tais como reservas e depreciação, por exemplo.

De igual forma, Oliver (1974) aplicou técnicas de diferenciação semântica entre membros de sete grupos profissionais para verificar se determinados conceitos contábeis apresentavam diferentes significados. Os resultados confirmaram a hipótese de que alguns termos não são bem compreendidos até mesmo por estudantes e profissionais de Contabilidade. Problemas semelhantes também foram detectados por Adelberg (1977), Belkaoui (1980), Houghton (1988) e Johnson (1991).

É preciso considerar que o valor das informações depende da capacidade que elas tenham de melhorar o conhecimento sobre determinada realidade, reduzindo riscos e incertezas, de tal maneira que seus destinatários se sintam mais apoiados no processo decisório. Com razão, pode-se argumentar que isso depende também de outros atributos qualitativos além da compreensibilidade, como, por exemplo, pontualidade, adequação ao modelo decisório, etc. Porém, não se pode negar que se a informação for incompreensível todo o esforço de produzi-la será inválido. Aliás, em tal circunstância, sequer mereceria ser conceituada como informação, mas simplesmente como um conjunto de dados desprovidos de qualquer valor semântico.

Esse aspecto é bem salientado por Guerreiro
(1989:133) ao explicar que, em muitas ocasiões, os sistemas de informação são concebidos sem considerar se o destinatário da mesma se encontra em condições de compreendê-la e utilizá-la em todo o seu potencial. Esse autor destaca que, quando o usuário não consegue compreender a informação com facilidade, tende a ignorá-la e se sente estimulado a criar sistemas paralelos, de caráter informal, para atender a suas necessidades. Corroborando esse pensamento, Adelberg (1977:101) explica que, em última instância, o propósito central da Contabilidade é alcançar êxito no processo de comunicação, permitindo que suas mensagens sejam bem compreendidas e utilizadas como luzes no processo decisório.

\section{REFERENCIAL TEÓRICO}

Revisando a literatura contábil, verifica-se que, há muito tempo, diversos autores vêm alertando para o problema da compreensibilidade das informações contábeis. Em geral, afirma-se que tão importante quanto produzir a informação certa é garantir que ela se torne compreensível ao usuário, para que ele possa utilizá-la como instrumento de apoio ao processo decisório.

De fato, se a Contabilidade tem por missão facilitar a tomada de decisões, o mínimo que se pode esperar das demonstrações contábeis são informações claras e compreensíveis, a fim de que o usuário possa identificar as alternativas de ação e selecionar a que mais se afine com seus objetivos.

Segundo Griffin e Williams (1963:787-88), ao longo dos tempos, refinamentos ocorridos na prática contábil têm produzido uma variedade de novos termos e expressões, gerando grande confusão para o leitor menos afeito a tais evoluções. Esses autores acrescentam que embora não se possa culpar o Contador pelo desejo de conferir uma feição mais estilizada aos contornos de sua atividade, pelo menos deve-se considerar que a conseqüência de tal refinamento, quando desacompanhado da preocupação de que a terminologia empregada possa ser compreendida, gera efeitos desastrosos, comprometendo a própria utilidade das demonstrações contábeis.

De acordo com Anderson (1963:60), a linguagem contábil tem se desenvolvido com o uso de palavras incorporadas ao cotidiano das pessoas, mas, "contraditoriamente, isso acaba prejudicando o en- 
tendimento das demonstrações contábeis, porque normalmente a Contabilidade atribui a tais palavras e frases um significado muito específico e distanciado do entendimento que elas poderiam produzir numa conversação normal". Esse autor entende que os Contadores estariam prestando um serviço de meIhor qualidade aos analistas financeiros se padronizassem a nomenclatura e as interpretações utilizadas nas demonstrações contábeis de vários grupos de empresas.

Segundo Goldberg (1965:368), em Contabilidade, como em qualquer outro campo do conhecimento que envolve relações humanas, observa-se uma considerável pressão no sentido de preservar uma linguagem familiar e pouco especializada, evitandose, contudo, termos que, apesar de comuns, carregam significados imprecisos. Esse autor explica que, infelizmente, na literatura contábil "pouquíssimas" expressões podem ser usadas inequivocamente sem qualquer risco de serem mal interpretadas. Segundo ele, esse problema, por si só, já é suficiente para justificar um enorme volume de entendimentos distorcidos sobre o conteúdo de demonstrativos contábeis.

Referindo-se ao processo da evidenciação contábil, Hendriksen e Breda (1992:873) afirmam que tão importante quanto a forma que se atribui às demonstrações contábeis são as descrições nelas utilizadas e o grau de detalhamento empregado. Os autores salientam que o uso de títulos e descrições apropriados podem ser esclarecedores para o leitor, ao passo que termos obscuros só podem levar à confusão ou incompreensão. Na seqüência, eles destacam que termos técnicos só podem ter utilidade caso possuam significados precisos e sejam geralmente bem conhecidos. Finalmente, adverte-se que, em Contabilidade, muitas expressões técnicas carecem dessa precisão.

ludícibus (1997:113) também concorda que "é importante utilizar, nas demonstrações, uma terminologia clara e relativamente simplificada". Esse autor acrescenta que "termos (e grupos) obscuros como 'resultado pendente', 'pendente' ou mesmo resultado de exercícios futuros devem ser evitados, por não serem precisos."

ljiri (1975:14) afirma que a Contabilidade, como linguagem dos negócios, tem muito em comum com outros tipos de linguagem. Esse autor explica que, da mesma forma como a imprensa precisa seguir certas regras no uso de uma língua para veicular informações de interesse público, a Contabilidade também deve observar regras específicas para comunicar os eventos de natureza econômica que interessam aos usuários das informações contábeis. Continuando, esse autor alerta que a inobservância de certas regras não apenas poderá gerar interpretações distorcidas, mas também acarretar riscos de penalidades para o contador em razão de "má representação, falsidade ideológica ou perjúrio". Por fim, ljiri salienta que, como qualquer outro tipo de linguagem, a Contabilidade deve ser flexível para se adaptar às mudanças ambientais e procurar acompanhar as características dos usuários, especialmente no que se refere às suas capacidades cognitivas.

Segundo Devine (1985), a Contabilidade tem sido inundada com tantos chavões, estereótipos e frases desprovidos de significados objetivos, que chega a se configurar como um agregado de "palavras tiranas" que bloqueiam uma comunicação eficiente.

Laudie (1987:579-604) refere-se à Contabilidade como um processo de comunicação bidirecional e interpessoal, e destaca que é importante questionar o significado do que está sendo comunicado aos usuários das informações contábeis, uma vez que a linguagem se caracteriza como um instrumento de comunicação que requer ajustes continuados em função dos agentes que participam do processo.

Referindo-se ao mesmo problema, Johnson (1991:11) afirma que a terminologia contábil tem se expandido tanto quanto a própria profissão, de tal forma que conceitos e termos empregados na Contabilidade Gerencial, por exemplo, se distanciam cada vez mais de uma base contábil única e consistente, passando a incorporar significados oriundos de diversos ramos de conhecimento como Economia, Engenharia, Finanças, etc. Comprovando essa afirmação, McCabe (1973) constatou que algumas palavras freqüentemente empregadas na área de custos apresentavam significados completamente diferentes em seis manuais de apenas duas organizações profissionais pertencentes ao mesmo ramo de atividade.

Ainda segundo Johnson (1991), alguns órgãos ligados à profissão contábil, a exemplo do AICPA e da Associação Americana de Contabilidade, vêm reconhecendo a existência de problemas 
terminológicos, razão pela qual têm publicado manuais de "definições" objetivando uniformizar a adoção de certos termos entre os profissionais responsáveis pela geração das informações contábeis.

O problema da compreensibilidade das informações contábeis também já foi objeto de discussão na Organização das Nações Unidas - ONU, onde um grupo de especialistas em padrões internacionais de Contabilidade concluiu que a complexidade dos negócios não pode ser utilizada como desculpa para a apresentação de informações pouco inteligíveis. Em seus relatórios, os especialistas destacaram que a forma de apresentação, a terminologia adotada, os conceitos e hipóteses estabelecidos, devem ser expressos de maneira não ambígua e suficientemente explicitados para que a informação seja compreendida com garantia.

De modo semelhante, o Comitê de Padrões Contábeis Internacionais do International Accounting Standards Committee - IASC tem considerado que a evidenciação contábil deve ser clara e compreensível, ainda que influenciada por políticas contábeis que variam de empresa para empresa, tanto dentro de um mesmo país como de um país para outro. Entende-se que, em qualquer circunstância, o usuário da Contabilidade precisa de informações claras para fazer julgamentos adequados e adotar decisões racionais.

O FASB, através do Statement of Financial Accounting Concepts no. 1, estabelece que a evidenciação contábil deve fornecer informações que sejam úteis para investidores e credores atuais e em potencial, bem como para outros usuários que tenham por objetivo a tomada racional de decisões de investimento, crédito e outras semelhantes. Em 1980, definindo os atributos qualitativos das informações contábeis, através do Statement $\mathrm{n}$ ‥ 2, o referido órgão considerou que a compreensibilidade é um dos requisitos necessários para que um número mais amplo de usuários possa assimilar o significado de tais informações e utilizá-las adequadamente no processo decisório.

\section{FOCOS DE PROBLEMAS SEMÂNTICOS}

De acordo com Adelberg (1977), o foco de problemas semânticos constatados na comunicação contábil orientada para usuários externos não reside apenas no uso de expressões técnicas, mas está relacionado também com o hábito de os contadores atribuírem significados técnicos a palavras que são empregadas com sentido diferente na linguagem popular.

De fato, diversos pesquisadores, como Haried (1970), têm constatado que termos como depreciação, reservas, provisões, Lucros Acumulados e outros semelhantes costumam transmitir significado muito diferente da realidade que objetivam veicular. Goldberg (1965) também faz referência a esse fato mencionando que até mesmo usuários mais sofisticados como analistas financeiros relacionam o termo depreciação com o declínio no valor do bem. Segundo esse autor, raramente o termo "depreciação" é associado ao procedimento de alocação sistemática de custos.

A princípio, o desenvolvimento de uma terminologia técnica dentro de um determinado campo pode ser considerado como um passo necessário para reduzir problemas dessa natureza. Porém, conforme alerta ljiri (1975), embora conceitos complexos possam indicar progresso científico, não são necessariamente importantes em determinadas áreas. Esse autor esclarece que, em alguns ramos do conhecimento, a virtude da simplicidade pode ser muito mais relevante, e acrescenta que talvez a Contabilidade seja um desses, por representar "a linguagem dos negócios que é usada por muita gente."

De fato, é preciso considerar que nem sempre as demonstrações contábeis se dirigem a um público especializado, podendo incluir também pessoas que possuem pouco domínio das particularidades inerentes à terminologia contábil. É certo que a compreensão de informações contábeis requer algum conhecimento prévio sobre atividades econômicas e disposição para examiná-las cuidadosamente, conforme alerta o FASB, mas, mesmo assim, a experiência tem demonstrado que expressões mais sofisticadas como goodwill, equivalência patrimonial, resultado de exercícios futuros, ativo diferido e outras correlatas não são bem compreendidas sequer por usuários especializados, como investidores, e nem mesmo por estudantes de Contabilidade. O termo "reservas", por exemplo, costuma ser confundido freqüentemente com segregação de recursos financeiros para reposição de ativos específicos. 
Fatos dessa natureza foram comprovados em pesquisa realizada por Silva (1995) junto a administradores de empresas situadas na região metropolitana de São Paulo. O estudo procurou verificar se o código lingüístico utilizado pela Contabilidade estava sendo entendido pelos usuários das informações contábeis. Para tanto, selecionou-se uma amostra composta em $62,6 \%$ de pessoas oriundas dos cursos de Economia, Administração e Contabilidade, por se considerar que tais usuários possuíam conhecimentos razoáveis para alcançar uma boa compreensão das demonstrações contábeis. Os resultados evidenciaram que a maioria dos pesquisados que têm opinião formada sobre o grau de entendimento das informações contidas no Balanço Patrimonial não consegue compreendê-las por completo.

Quanto à terminologia adotada na elaboração dos demonstrativos contábeis, constatou-se que mais da metade dos pesquisados não consegue entender perfeitamente o significado da conta "Banco Conta Movimento". Em relação aos que não possuem formação contábil, a situação é bem pior. Para eles, o termo equivalência patrimonial se apresenta como algo quase que totalmente estranho. De igual forma, mais da metade dos pesquisados não compreendia adequadamente o significado da conta provisão para devedores duvidosos. Aliás, constatou-se que o termo provisão sequer foi compreendido pelos usuários em geral, o que indica ser aconselhável substituí-lo por outro capaz de expressar melhor a idéia que se deseja comunicar, conforme sugeriu a própria pesquisa. O mesmo foi constatado em relação aos termos Reserva de Capital e Saldo Credor da Correção Monetária, haja vista que a maioria dos usuários revelou desconhecer o significado preciso de ambos.

No mesmo trabalho, Silva declara que "mais da metade dos pesquisados gostariam que a Contabilidade utilizasse uma linguagem mais acessível aos não-contadores, que são a maioria dos usuários das informações contábeis". Por fim, a pesquisa sugeriu a realização de um levantamento completo dos termos técnicos utilizados pela Contabilidade, objetivando substituí-los por outros mais comunicativos, na medida do possível. Estudos dessa natureza demonstram que efetivamente existem graves problemas semânticos na comunicação contábil orientada a usuários externos.

Nos Estados Unidos, diversas pesquisas desse gênero têm sido realizadas no sentido de avaliar o grau de compreensibilidade das informações contábeis, principalmente no que se refere às chamadas evidenciações narrativas, onde se incluem as Notas Explicativas, Relatórios da Administração, Pareceres dos Auditores etc. Como exemplo, cite-se um estudo realizado por Gibson e Schroeder (1990:7887) para avaliar as características da linguagem utilizada na elaboração de Notas Explicativas contidas em demonstrações contábeis dos maiores bancos internacionais, situados em nove países de língua inglesa. Os autores partiram da hipótese de que a complexidade da linguagem poderia comprometer o processo de análise e interpretação efetuadas por credores, investidores e depositantes. Como resultado, observou-se que a terminologia empregada na elaboração das referidas notas explicativas foi considerada pela maioria dos pesquisados como "incompreensível" ou pouco reveladora dos fatos que deveriam explicar.

Em outros estudos realizados pelos mesmos autores, constatou-se que cerca de $60 \%$ dos investidores profissionais, embora já familiarizados com a complexa terminologia dos demonstrativos contábeis, consideraram que as informações seriam melhor compreendidas se as notas explicativas fossem redigidas numa linguagem mais compreensível e livre de jargões técnicos. Mesmo assim, verificou-se que termos que possuem significados bem estabelecidos no cotidiano das pessoas são menos compreendidos do que termos específicos da área contábil.

Para atenuar problemas dessa natureza Bedford (1965:7) sugere que se utilizem definições operacionais na comunicação de determinados eventos registrados pela Contabilidade. Exemplificando, esse autor considera que uma definição do tipo "alocações ao período corrente do custo original do ativo" expressa com maior perfeição a informação contábil que normalmente se busca transmitir através do termo "depreciação". De igual forma, Silva, na pesquisa retromencionada, recomenda alterar o termo "Equivalência Patrimonial" para "Ganhos ou Perdas de nossos Investimentos em Outras Empresas", tendo em vista que boa parte dos usuários da Contabilidade desconhecem seu significado. Embora isso exija esforços e experimentações para construir frases sucintas que representem conteúdos 
operacionais passíveis de serem transmitidos através dos demonstrativos contábeis, realmente pode valer a pena na medida em que contribua para reduzir sérios problemas semânticos derivados da terminologia presente.

Como se observa, diversas constatações empíricas realizadas ao longo do tempo comprovam a importância de se utilizar uma linguagem capaz de facilitar o entendimento dos usuários das informações contábeis e de comunicar com fidelidade os fenômenos que se busca representar. Nesse ponto, referência deve ser feita à lúcida observação de Martins (1998:24) sobre o problema terminológico: "desde que duas pessoas resolvam comunicar-se é importante que passem a dar aos objetos, conceitos e idéias o mesmo nome, sob pena de, no mínimo, reduzir-se o nível de entendimento". O referido autor completa afirmando: "o que comumente se denomina de mero problema de terminologia, talvez fosse melhor tratado como magno problema de terminologia".

Portanto, uma comunicação significativa de dados contábeis exige, entre outras coisas, que os responsáveis por sua preparação e aqueles que irão utilizá-los atribuam aproximadamente o mesmo significado para os símbolos adotados.

\section{A TEORIA DA COMUNICAÇÃO APLICADA À EVIDENCIAÇÃO CONTẢBIL}

Caracterizada a existência de problemas semânticos no processo de comunicação das informações contábeis, torna-se necessário identificar metodologias que possam contribuir para eliminá-los ou pelo menos reduzi-los. Neste tópico, tentaremos explicar como os fundamentos da Teoria da Comunicação podem ser utilizados com esse objetivo.

Reconhecendo que a comunicação é um elemento essencial ao cumprimento das funções inerentes à Contabilidade, diversos autores propõem que se utilizem os princípios da Teoria da Comunicação para melhorar a qualidade das informações contábeis. Bedford e Baladouni (1962), por exemplo, salientam que se os conceitos da referida Teoria têm sido aplicados com muito êxito em diversos ramos do conhecimento humano, como a psicologia experimental, a lingüística e a biofísica, então deveríamos tentar aproveitá-los para aprimorar o processo da comunicação contábil.
Os referidos autores explicam que, para tanto, o primeiro passo consiste em entender que a Contabilidade é de fato um processo de comunicação e que o mesmo se desenvolve em duas dimensões: a dimensão da observação e a dimensão da produção. A primeira dimensão é constituída das seguintes etapas: recebimento de informações sobre os eventos econômicos da empresa, interpretação dessas informações e seleção daquela que deverá ser comunicada. Já a dimensão da produção, segundo os autores, se caracteriza por envolver as seguintes atividades: codificação da informação e transmissão desta para o usuário.

Partindo dessa visão, Bedford e Beladouni (1962) desenvolveram um modelo para descrever e avaliar o processo da comunicação contábil, tendo como estrutura os seguintes elementos: os eventos econômicos, o contador, os demonstrativos contábeis e o usuário das informações neles contidas. Adicionalmente, o referido modelo incorpora os conceitos de fidelidade e significância, objetivando caracterizar, respectivamente, a relação desejada entre o contador e o usuário e a relação entre os demonstrativos contábeis e os eventos econômicos. Nesse contexto, significância diz respeito ao grau de relevância e adequação com que a Contabilidade consegue descrever os eventos econômicos, ao passo que fidelidade se refere à correspondência que deve existir entre os significados que o usuário atribui às mensagens e aqueles que o contador pretende transmitir.

Diversos depoimentos sobre a Teoria da Comunicação sugerem que a proposta de Bedford e Baladouni é pertinente no sentido de aproveitá-la para aprimorar o processo da comunicação contábil. Hayakawa (1967:336), por exemplo, afirma que a Teoria da Comunicação tem contribuído para a sobrevivência do homem e a evolução da própria sociedade como um todo, na medida em que fornece elementos conceituais necessários à construção e à melhoria de instrumentos que nos permitem compartilhar experiências, valores culturais, e aprimorar as interações humanas através da comunicação.

Smith (1972) destaca que a Teoria da Comunicação tem influenciado o desenvolvimento de muitos ramos do conhecimento humano, especialmente no campo das pesquisas relacionadas com neurologia, tecnologias de mídia, lingüística, psicologia, psiquiatria, comportamento de grupos, teoria das organiza- 
ções, desenvolvimento de sistemas de informações, economia, pedagogia, entre outras.

Referido-se às diversas aplicações da Teoria da Comunicação, Epstein (1988) procura demonstrar que a mesma se desenvolveu de tal forma que adquiriu importância considerável em diversas áreas como psicolingüistica, economia, desenho industrial, biologia, psicologia, etc. Esse autor explica que os fundamentos da Teoria da Comunicação têm sido aplicados com sucesso em processos de avaliação de textos lingüísticos, tanto no que se refere à informação objetiva, calculada exclusivamente a partir de medidas efetuadas sobre o texto, quanto à subjetiva, computada quando se leva em conta o desempenho de determinados sujeitos ou classes de sujeitos frente a textos.

Assim, conclui-se pela conveniência de se examinarem os conceitos básicos da Teoria da Comunicação, objetivando compreender como a mesma pode ser aplicada ao campo da Contabilidade e identificar que contribuição ela pode oferecer ao aprimoramento da comunicação contábil.

\subsection{Os Componentes do Processo de Comunicação}

Em termos gerais, comunicação pode ser definida como a transferência de informações de uma determinada fonte para um receptor. Como o objetivo de um comunicador é realizar esse processo de maneira eficiente, estudiosos dessa área têm procurado desenvolver determinados modelos visando ao aprimoramento da comunicação.

A Teoria da Comunicação foi desenvolvida inicialmente por Claude Shannon (1949), sob uma abordagem matemática, para resolver problemas relacionados com a transmissão de sinais no campo das telecomunicações. O modelo geral de comunicação concebido por Shannon, em versões mais reduzidas, contempla três dimensões: a dimensão técnica, a semântica e a pragmática. A primeira dimensão se relaciona com o processo técnico de transmissão dos sinais; a dimensão semântica diz respeito à precisão com que os símbolos podem "transportar" os significados desejados e a dimensão pragmática diz respeito à eficiência com que os "significados recebidos" despertam comportamentos.

O referido modelo é composto dos seguintes elementos: emissor, mensagem, código, canal e recep- tor. O emissor, como o próprio nome sugere, é um transformador de sinais que tem por finalidade codificar a mensagem e torná-la compreensível ao destinatário; a mensagem, por sua vez, é o instrumento que une o emissor ao receptor, permitindo veicular diversos conteúdos, tais como: ordens, instruções, pedidos, sugestões, opiniões, etc.; o código pode ser considerado como um sistema de regras que relacionam seus usuários sob a forma de reciprocidade para tornar inteligível o conteúdo da mensagem; o canal é o meio utilizado para transportar a mensagem e tem como requisitos básicos: facilidade de manuseio e de reprodução, durabilidade, facilidade de conservação, resistência etc. Assim como o código, o canal precisa ser dominado tanto pelo emissor quanto pelo receptor e ainda ser compatível com o tipo de mensagem que se deseja transportar. Por último, temos o receptor, que é o destinatário da mensagem.

Explorando a estrutura do modelo geral de comunicação, Maser (1975) explica que o objetivo da comunicação é partilhar informações e que o mesmo pode ser prejudicado por diversos fatores, tais como: "o emitente não se expressa de maneira adequada, dizendo algo diferente do que pretendia; $b$ ) o receptor compreende a mensagem de modo inapropriado, que não se coaduna com a intenção do emitente; c) a mensagem recebida difere da enviada, por ter sido deturpada ou alterada enquanto era transportada".

De acordo com Berlo (1960), desde que haja um objetivo a comunicar, uma resposta a obter ou um comportamento a modificar através do ato comunicativo, espera-se deste a maior fidelidade possível. Assim sendo, importa discutir quais os fatores associados à fonte, ao receptor, à mensagem e ao canal que determinam a eficiência da comunicação.

\subsubsection{O EmISSOR}

Entre os fatores que atuam sobre o emissor da mensagem, influenciando seu comportamento no ato comunicativo, seu objetivo, seus mecanismos codificadores e o conteúdo das mensagens, destacam-se: as habilidades comunicativas; o grau de conhecimento que ele possui a respeito do objeto e do próprio processo da comunicação e, finalmente, sua posição dentro do sistema sóciocultural.

Considera-se que os níveis de habilidade comu- 
nicativa determinam a fidelidade da comunicação na medida em que influenciam a capacidade individual de analisar os próprios objetivos e intenções, bem como a capacidade de codificar a mensagem de maneira a expressar o que se pretende.

O nível de conhecimento é mais um fator a ser considerado nesse contexto, e diz respeito tanto ao conhecimento do assunto que deverá ser veiculado através da mensagem, quanto ao próprio processo de comunicação. Aliás, afirma-se que o conhecimento do referido processo é um dos fatores que mais influencia o grau de fidelidade, pois este depende em muito do nível de conhecimento que a fonte possui sobre as características do receptor, sobre os meios pelos quais poderá produzir ou tratar as mensagens e também sobre os tipos de canais que poderá utilizar para conduzi-la.

O último fator considerado nesse contexto, é o sistema sociocultural. Para demonstrar como o mesmo influencia o processo de comunicação, Berlo (1999) afirma que nenhuma fonte se comunica como livre agente sem ser influenciada por sua posição no sistema sociocultural. Portanto, entende-se que é necessário conhecer o tipo de sistema social em que ela opera, o contexto cultural no qual se comunica, as crenças e os valores culturais que the parecem dominantes, as formas de comportamento aceitáveis ou não aceitáveis, exigidas ou não exigidas em sua cultura, etc. Como se observa, a posição da fonte no contexto sociocultural realmente poderá afetar o seu comportamento no processo de comunicação, na medida em que ela cumpre papéis específicos e possui percepções ou imagens variáveis sobre a posição social e cultural do receptor.

\subsubsection{O Receptor da Mensagem}

Segundo Schmutte (1983:24), cada elemento que integra o processo de comunicação pode influenciar o grau de fidelidade alcançado na transmissão de determinada mensagem. Porém, esse autor afirma que, em termos de impacto sobre a eficiência geral do processo, o receptor é o componente crítico. Considera-se que seu desempenho na decodificação da mensagem pode ser afetado por vários fatores, mas nenhum deles é tão importante quanto o grau de conhecimento que ele tenha sobre o código utilizado pela fonte. Se o receptor não conhecer o código empregado na composição da mensagem, não poderá interpretá-la, independentemente dos cuidados que a fonte possa ter adotado para estruturá-la.

Seguindo o mesmo raciocínio, Berlo (1999) também destaca que o receptor é o elo mais importante em qualquer processo de comunicação, salientando que se a mensagem não o atingir de maneira compreensível, inútil terá sido o esforço de enviá-la. De fato, observa-se que na Teoria da Comunicação, o receptor ocupa posição de grande destaque. As seguintes considerações de Bloomfield (1933) ilustram bem essa importância:

"A preocupação com o receptor é um princípio orientador para qualquer fonte de comunicação. Ele tem sempre de ser lembrado, quando se decide sobre cada um dos fatores ligados à comunicação. Quando a fonte escolhe um código para a mensagem, deve escolher um que seja conhecido do receptor. Quando a fonte seleciona o conteúdo, a fim de refletir seu objetivo, seleciona um conteúdo que tenha significação para 0 receptor. A única justificativa para a existência da fonte e para a ocorrência da comunicação, é o receptor, o alvo ao qual tudo é destinado." (grifos nossos)

Assim como as habilidades comunicadoras da fonte são importantes para capacitá-la a interpretar os eventos, criar e codificar a mensagem, as habilidades relacionadas com o receptor também são essenciais à efetividade da comunicação, pois delas depende a decodificação da mensagem recebida. Por isso, não se pode predizer o êxito do ato comunicativo apenas em função das habilidades da fonte ou do receptor, isoladamente, mas sempre em conjunto.

\subsubsection{A Mensagem}

Além da fonte e do receptor, outro elemento que também influencia a qualidade da comunicação é a mensagem. $\mathrm{Na}$ análise desse componente, três elementos estruturais devem ser considerados: o código, o conteúdo e a forma como é tratada.

O código geralmente é definido como qualquer grupo de símbolos capaz de ser estruturado de maneira a produzir significados para alguém. Sob o enfoque das ciências que estudam as linguagens, como a Semiótica, por exemplo, a interpretação que o receptor poderá atribuir aos códigos pode ser considerada em três níveis: a) sintático: reconhecimento de um código em conexão com outros códigos (sen- 
tido lógico); b) semântico: compreensão do significado que o emissor pretendeu despertar através dos códigos; c) pragmático: interpretação dos códigos em termos de relevância, concordância ou discordância, etc. A mais simples tarefa de interpretação de qualquer mensagem requer certo grau de familiaridade com o código que está sendo utilizado. Portanto, é necessário identificar até que ponto o destinatário da mensagem está apto a compreendêlo, conforme já se destacou.

No que se refere ao conteúdo da mensagem, o mesmo deve ser entendido como a substância escoIhida pelo emissor para exprimir seu objetivo. Considerando que o receptor é o foco do processo de comunicação, a definição do conteúdo de uma mensagem deve levar em consideração, pelo menos, os seguintes fatores: o tipo de informação que o usuário deseja encontrar, que uso fará dela e como o sistema de informação poderá ser projetado para satisfazer suas necessidades.

Se a mensagem não for relevante diante dos objetivos do usuário, inútil terá sido o esforço de produzi-la. Assim, pode-se afirmar que comunicação eficiente é aquela que transporta informações úteis, fornecendo subsídios para que o homem possa decidir com maior segurança. Quando se trata de definir o conteúdo de uma mensagem, o emissor deve considerar que o ser humano raramente busca informação como um fim em si mesma. Ao contrário, ela é procurada para apoiar o processo de tomada de decisão, objetivando solucionar problemas, alocar recursos etc. Por isso, é necessário considerar a visão do usuário, suas necessidades e opiniões entre outros fatores relevantes.

\subsubsection{O Canal}

Para completar a análise sobre o processo de comunicação, restam algumas observações a respeito do canal, que é o veículo utilizado para transportar a mensagem.

A fonte, ou codificador, precisa identificar a melhor maneira de atingir o receptor, ao menor custo possível. Desse modo, a decisão sobre o tipo de canal utilizado no transporte da mensagem depende de um conjunto de fatores, entre os quais destacam-se: adequação ao conteúdo da mensagem, ao código utilizado, às características do receptor, custo etc. A própria fonte também acaba influenciando a escolha do ca- nal, na medida em que se comunique melhor desta ou daquela maneira. Por exemplo: falando, utilizando linguagem gráfica, demonstrando fisicamente, etc.

Assim, todos os elementos que compõem o processo de comunicação devem ser considerados de forma integrada, e nunca isoladamente. Em se tratando de avaliar a eficiência da comunicação, torna-se necessário contemplar múltiplos aspectos: habilidades comunicadoras da fonte e do receptor, seus níveis de conhecimento sobre o assunto veiculado, papéis no sistema social, o contexto cultural onde se encontram inseridos, adequação do código, conteúdo da mensagem, compatibilidade do canal, etc.

\section{CONCLUSÕES E RECOMENDAÇÕES}

Considerando que o processo de comunicação contábil incorpora os elementos conceituais da Teoria da Comunicação, observa-se que a mesma realmente pode fornecer subsídios para o aprimoramento das informações contábeis, na medida em que expõe as funções inerentes a cada componente do ato comunicativo, bem como as relações que se estabelecem entre eles.

Desenvolvendo uma análise crítica sobre a aplicação da Teoria da Comunicação à Contabilidade, Smith (1972) comprovou que seu arcabouço conceitual contribui para se identificarem fatores prejudiciais à qualidade das informações contábeis, como, por exemplo, a adoção de termos que não se apresentam ao alcance da compreensão de seus usuários. $\mathrm{O}$ autor considera que a referida teoria favorece o desenvolvimento de pesquisas na área contábil, além de permitir aprimoramentos nos sistemas de informação, tanto no aspecto operacional como em suas relações com o usuário.

No estudo referenciado, Smith constatou também que as informações contábeis podem sofrer distorções em função de problemas semânticos desde o momento em que são produzidas. Isso acontece quando os produtores da informação não conseguem interpretar adequadamente os eventos econômicos que deveriam comunicar ou quando possuem níveis de compreensão diferenciados em relação a princípios e normas que orientam a prática contábil.

Nesse caso, o mínimo que se pode afirmar sobre 
a qualidade das informações geradas é que um mesmo evento econômico pode estar sendo relatado de diversas maneiras, tanto no aspecto qualitativo como no quantitativo. Diante disso, a informação perde significado como instrumento de apoio ao processo decisório, ainda que seu destinatário consiga compreendê-la adequadamente, haja vista que a fidelidade na representação dos fatos e uniformidade ficaram prejudicadas.

Outra lição que pode ser extraída da Teoria da Comunicação é que a fonte produtora das informações deve procurar reconhecer as necessidades de cada estrato de usuário e avaliar sua habilidade em interpretar a informação adequadamente. Nesse sentido, Hendriksen (1992) salienta que o tipo e a quantidade de evidenciação são fatores que dependem, pelo menos em parte, da capacidade que o leitor possua para interpretar dados contábeis. Seguindo esse mesmo raciocínio, ludícibus (1997) explica que é necessário considerar, "em cada circunstância de espaço e tempo", a qualidade e a quantidade de informação que o usuário pode assimilar. Esse autor reforça suas considerações afirmando que:

"De pouco ou quase nada poderá adiantar uma grande empresa industrial, que opera, admitamos, na área de uma grande tribo do interior da África, editar seus demonstrativos contábeis com a inclusão de uma dose de evidenciação que vá ao ponto de incluir valores estimados, com várias distribuições de probabilidades, análises de regressão de dados passados etc., pois, possivelmente, o nível médio do leitor (supondo que os membros da tribo estivessem interessados em investir em uma multinacional) não teriam background educacional suficiente para 'digerir' tal forma de evidenciação."

Estas considerações demonstram que os limites da evidenciação devem ser estabelecidos em função das características e necessidades dos usuários, observando-se os conceitos de relevância e materialidade, para permitir uma compreensão satisfatória de todos os elementos contábeis que possam influenciar as decisões.

Desse modo, fica claro que o importante não é transmitir a maior quantidade possível de informação, mas fornecer a informação necessária, de forma compreensível, numa relação custo/benefício otimizada, para que o usuário possa alcançar meIhores resultados no processo decisório.

A Teoria da Comunicação deixa claro que os significados não são propriedades das palavras, mas dos indivíduos. Discorrendo sobre o processo da comunicação, Berlo (1999:184) ensina que se os sentidos fossem encontrados nas palavras, qualquer pessoa compreenderia qualquer linguagem, qualquer código. $\mathrm{Na}$ seqüência, esse autor esclarece que "algumas pessoas têm sentido para certos códigos, outras não".

Portanto, para corrigir problemas relacionados com a compreensibilidade das informações contábeis, o presente trabalho propõe que se realizem pesquisas periódicas no sentido de levantar as características médias de estratos de usuários, a fim de identificar eventuais dificuldades e elementos significativos que devem ser considerados no uso da terminologia contábil. Um possível passo inicial é verificar se tais usuários atribuem às informações o mesmo significado que os contadores pretendem transmitir com a terminologia atual.

\section{REFERÊNCIAS BIBLIOGRÁFICAS}

ADELBERG, Arthur Harris. Narrative disclosures contained in financial reports: an empirical avaluation of their understandability. Unpublished Ph. D. dissertation, City University of New York, 1977.

\section{AMERICAN ACCOUNTING INSTITUTE OF CERTIFIED PUBLIC ACCOUNTANTS.} Statement $n \div$. 4. New York: AICPA/APB, 1973.
ANDERSON, D. S. "Communications problems of financial reporting", The Journal of Accountancy, CXV, abril/1963 p.60.

ANTHONY, R. N. \& REECE, J. S. Management Accounting: Text and Cases. Homewood, IL: Irwin, 1975.

BAKER III, H. E. \& KARE, D. D. Relationships 
Between Annual Report Readability and Corporate Financial Performance. Management Research News, Vol. 4, 1992:1-4.

BEDFORD Norton M. \& BALADOUNI Vahe. A Communication Theory Approach to Accounting, Accounting Review, 1962: 650-659.

BELKAOUI, Ahmed. The interprofessional linguistic communication of accounting concepts: An experiment in sociolinguistics. Journal of Accounting Research, Vol 18, n‥2, Autumn, 1980,p.362-374 .

BERLO, David. The Process of communication: An introduction to theory and practice. New York: Holt, Rinehart and Winston, 1960.

BERLO, David K. O processo da comunicação: introdução à teoria e à prática; tradução Jorge Arnaldo Fontes. 9. ed. São Paulo: Martins Fontes, 1999.

BLOOMFIELD, Leonard. Language. New York Henry Holt and Company, 1933.

BRANDELL F. The Wheels of Commerce (Civilization and Capitalism, $15^{\text {th }}-18^{\text {th }}$ Century). New York: Harper and Row, 1979.

CARVALHO, L. Nelson. Contabilidade \& Ecologia: Uma exigência que se impõe. Revista Brasileira de Contabilidade. n. 75, abril/julho 1991 p.20-25.

Devine, Carl Thomas. Essays in Accounting Theory. Vol. 1, Sarasota, Fl. American Accounting Assocation, 1985.

DOPUCH, Nicholas, SUNDER, Shyam. Fasb's Statements on objectives and elements of financial accounting: a review. The Accounting Review, jan. 1980 p.11.

EPSTEIN, Isaac. Teoria da informação. 2. ed. São Paulo: Ática, 1988.

GOLDBERG, L. An inquiry into the nature of Accounting. Evanston, II: American Accounting Association, 1965.

GOLUB, S. J. \& KUEPPERS, R. J. Summary
Reporting of Fianacial Information: Moving Toward More Readable Annual Reports. Financial Executives Research Foundation, 1983, Foreword.

GUAGLIARDI, José Rafael. A Evidenciação de Informações em Companhias Abertas - Um Estudo Exploratório. Tese de Doutoramento apresentada à FEA/ USP, São Paulo, 1987.

GUERREIRO, Reinaldo. Modelo conceitual de sistema de informação de gestão econômica: uma contribuição à Teoria da Comunicação da Contabilidade. Tese de Livre Docência apresentada à FEA/USP, São Paulo, 1989.

HARIED, Andrew Amil. A inquiry into semantic problems of exterrnal accounting communication: a comparative study of research techniques. Unpublished Ph. D. dissertation, University of Illinois, 1970.

HAROLD, B. Jr. e DREBIN, Alan R. Contabilidade Gerencial. Tradução de Mauro Batista Temer. 2. ed. Rio de Janeiro: Guanabara Dois, 1979.

HAYAKAWA, S. I. Language in thought and action. 3. ed. New York: Harcourt, Brace Jovanovich, Inc., 1972.

HENDRIKSEN, Eldon S. \& BREDA, Michael F. Van. Teoria da Contabilidade. Trad. de Antônio Zoratto Sanvicente. 5. ed. São Paulo: Atlas, 1999.

HENDRIKSEN, Eldon S; BREDA Michael F. Van. Accounting Theory. 5. ed. Chicago: Irwin, 1999. . Teoria da Contabilidade.2. ed. São Paulo: Atlas, 1987.

HORNGREN, Charles T. Accounting for Management Control. Englewood Cliffs, NJ: Prentice-Hall, 1974.

HOUGHTON, Keith A. The measurement of meaning in Accounting: A critical analysis of the principal evidence. Accounting Organizations and Society , vol 13, no. 3, 1988, p. 263-280.

IJIRI Y. Theory of Accounting Measurement. Sarasota, FL: American Accounting Association, 1975 
IPECAFI, IBRACON. Estrutura Conceitual Básica da Contabilidade. São Paulo, 1986.

IUDíCIBUS, Sérgio de. Teoria da Contabilidade. 5. ed. São Paulo: Atlas, 1997.

JOHNSON, Steven D. An empirical study of the fidelity of organizational accounting communication and the impact of organizational culture. Ph. D. dissertation, Virginia Polytechnic Institute and State University, 1991.

JONES. A Longitudinal Study of the Readability of the Chairman's Narrative in the Corporate Reports of a UK Company. Accounting and Business Research 18 (1988): 297-305.

LAKATOS, Eva Maria, MARCONI, Marina de Andrade. Metodologia do Trabalho Científico. 4. ed. São Paulo: Atlas, 1992.

LAUDIE, D. The accounting of interpretations and the interpretation of accounts. Accounting, Organizations and Society (Junho 1987): 579604.

LESIKAR, R. L. \& LYONS, M. P. Report Writing for Business. Homewood, Illinois : Irwin, 1986.

MARTINS, Eliseu. O Papel da Profissão na Regulação dos Mercados, Revista Brasileira de Contabilidade, n. 80: 62-69.

MARTINS, Eliseu. Contabilidade de Custos. 6. ed. São Paulo: Atlas, 1998.

McCONNELL, D. , HASLEM, J. A., GIBSON, V. R. The President's Letter to Stockholders: A New Look, Financial Analises Journal 5, 1986: $67-70$.

MILLS P. A. Words and The Study of Accounting History, Accounting, Auditing and Accountability Journal, (janeiro 1990): 21-35.

MOONITZ, Maurice. The basic postulates of accounting. New York : AICPA, 1961.

MOST, Kenneth S. Accounting Theory. Colombus : Grid, 1977.

OLIVER, Bruce L. The semantic differential: a device for measuring the interprofessional communication of selected accounting concepts. Journal of Accounting Research, Autumn, 1974, p. 299-316.

POUND, G. D. A note on audit report readability. Accounting and Finance (Maio 1981): 45-55.

SCHMUTTE, James Leonard. An empirical investigation of the fidelity of accounting communication. Unpublished Ph. D. dissertation, University of Kentucky Lexington, 1983.

SCHROEDER, N. GIBSON, C. Readability of Management's Discussion and Analysis, Accounting Horizons, dezembro 1990p.78-87.

SHANNON, Claude E. \& WEAVER, Warren. The mathematical theory of communication. Urbana, Illinois: University of Illinois Press, 1949.

SILVA, Benedito G. da. Sistema de informação contábil sob a ótica da teoria da comunicação: um estudo com administradores na região da Grande São Paulo. Dissertação de Mestrado apresentada à FEA/USP, São Paulo, 1995.

SMITH, James E. \& SMITH, Nora P. Readability: A measure of the performance of the communication function of financial reporting. Accounting Review (Julho 1971):352-361.

SMITH, James Emanuel. A critical analysis of the application of communication theory to accounting communications via published financial statements. Ph. D. dissertation, University of Arizona, 1972.

SMITH, M. \& TAFFLER, R. The Chairman's Statement and Corporate Financial Performance. Accounting and Finance 1, 1992:75-90.

SPROUSE, Robert T., MOONITZ, Maurice. A tentative set of broad accounting principles for business enterprises. New York : AICPA, 1962.

VAINI, Luis Carlos. O Auditor do Futuro. Trabalho apresentado no XIV Congresso Brasileiro de Contabilidade. Salvador, outubro de 1992.

WORTHINGTON, J. S. Making Fianancial Statement Footnotes More Readable. C.A. Magazine, september, 1977, p. 34-37. 